\title{
Upaya Motivasi Untuk Meningkatkan Kinerja Karyawan Pada PT. Federal Internasional Finance (FIF) Di Muara Enim
}

\author{
Novita Sari ${ }^{1}$, Apriansyah ${ }^{2}$ \\ Program Studi Ekonomi STIE Serasan Muara Enim \\ Email : novitasari2074@yahoo.com
}

\begin{abstract}
Abstrak
Tujuan penelitian ini adalah untuk mengetahui upaya yang dilakukan, teknik motivasi yang digunakan, serta sejauh mana tingkat motivasi kerja pada PT. Federal Internasional Finance (FIF) Di Muara Enim. Metode penelitian yang digunakan adalah metode observasi, wawancara, kuesioner, dokumentasi, dan studi pustaka. Hasil penelitian menunjukkan bahwa upaya peningkatan kinerja karyawan pada PT. Federal Internasional Finance (FIF) Di Muara Enim dengan disiplin kerja karyawan, yaitu upaya pimpinan dalam meningkatkan kinerja melalui motivasi adalah meliputi penetapan disiplin, pengawasan, menciptakan iklim yang kondusif, pemberian insentif, dan kompensasi, menerapkan sistem keadilan dan melalui pendekatan preventif, adanya komunikasi antara atasan dan bawahan untuk menghindari terjadinya kesenjangan sosial yang dirasakan oleh karyawan.
\end{abstract}

Kata kunci: Motivasi, Kinerja Karyawan, Disiplin Kerja

\section{PENDAHULUAN}

\section{I.1 Latar Belakang}

Perkembangan teknologi yang semakin maju dari masa ke masa membuat persaingan dalam dunia pekerjaan meningkat. Hal ini dikarenakan adanya globalisasi dan modernisasi. Jika suatu organisasi atau instansi tidak bisa menyingkapi hal tersebut, maka kelangsungan kegiatan atau pekerjaan di dalam organisasi atau instansi tersebut akan terhambat. Sebuah instansi harus didukung sumber daya manusia yang cakap karena sumber daya manusia sangat berperan dalam menjalankan usaha atau kegiatan di dalam instansi tersebut (Soekidjo Notoatmodjo, 2003:2).

Manajemen sunber daya manusia berperan sebagai penghubung antara orang-orang dengan perusahaan untuk mewujudkan tujuan tertentu melalui kegiatan orang lain. Dalam hal ini manajemen sumber daya manusia menetapkan program kerja dan peraturan kepegawaian pada karyawan, keikutsertaan karyawan berperan aktif dalam perusahaan diharapkan dapat menjalankan kegiatan perusahaan dengan sempurna serta sesuai dengan tujuan yang diharapkan manager. Sebaliknya karyawan mendapatkan balas jasa atas pencapaian yang diinginkan perusahaan.

PT. Federal Internasional Finance (FIF) merupakan salah satu perusahaan yang bergerak dalam bidang pembiayaan, sewa guna usaha (leasing). Dalam melakukan usahanya tidak jauh berbeda dengan jenis-jenis perusahaan leasing lainnya. Sebab didalam organisasinya menghendaki juga pola hubungan kerja antara orang-orang yang berbeda pada setiap satuan organisasinya.

Fenomena yang dialami perusahaan PT. Federal Internasional Finance (FIF) Muara Enim adalah peraturan karyawan yang sering dilanggar dengan ada yang datang terlambat, dan kalau tidak masuk kerja, tidak melampirkan surat keterangan izin. 
Peraturan di perusahaan ini sudah ada tetapi belum dilaksanakan dengan baik oleh karyawan, namun karyawan yang melanggar peraturan masih diberi teguran saja.

Dalam sistem penggajian yang ada di perusahaan ada yang tetap dan ada yang tidak tetap. Untuk karyawan yang tetap berupa gaji yang didapat karyawan setiap bulannya yang telah ditetapkan perusahaan, sedangkan yang tidak tetap berupa insentif yang apabila kinerjanya baik dan pencapaian target dapat terpenuhi setiap bulannya.

Bagi karyawan yang kinerjanya baik dan mencapai target tagihan setiap bulannya akan mendapatkan reward berupa insentif saja, sedangkan bagi karyawan yang kinerjanya kurang baik dan tidak mencapai target tagihan dalam satu bulan pertama yang telah ditentukan perusahaan akan mendapatkan funishment berupa SP 1, jika dalam 3 (tiga) bulan tidak mencapai target akan dikeluarkan SP 2. Kalau sudah keluar SP 2 akan di evaluasi dalam 2 (dua) bulan setelah itu baru SP 3. Dibawah ini dapat di lihat target tagihan PT. Federal Internasional Finance (FIF) Muara Enim adalah sebagai berikut.

Tabel 1

Target Tagihan PT. Federal Internasional Finance (FIF) Muara Enim Tahun 2015

\begin{tabular}{|c|l|l|c|c|}
\hline No & Karyawan & Konsumen & $\begin{array}{c}\text { Target } \\
\text { Tagihan/Bulan }\end{array}$ & $\begin{array}{c}\text { Angka } \\
\text { Pencapaian/Bulan }\end{array}$ \\
\hline 1 & Collection & 100 orang & $95 \%$ & $80 \%$ \\
\hline 2 & Recovery & 100 orang & $85 \%$ & $76 \%$ \\
\hline
\end{tabular}

Sumber: PT. Federal Internasional Finance (FIF) Muara Enim

Dari tabel 1 di atas, dapat terlihat bahwa target tagihan karyawan PT. Federal Internasional Finance (FIF) Muara Enim di tahun 2015 belum sepenuhnya mencapai target yang telah ditentukan.

Untuk target dalam penjualan pada PT. Federal Internasional Finance (FIF) Muara Enim dapat dilihat pada tabel di bawah ini.

Tabel 2

Target Penjualan PT. Federal Internasional Finance (FIF) Muara Enim Tahun 2015

\begin{tabular}{|c|c|c|}
\hline Nama & Target Penjualan/Bulan & Angka Pencapaian/Bulan \\
\hline Karyawan & 150 Unit & 150 Unit \\
\hline
\end{tabular}

Sumber: PT. Federal Internasional Finance (FIF) Muara Enim

Dari tabel 1 di atas, dapat terlihat bahwa target penjualan karyawan PT. Federal Internasional Finance (FIF) Muara Enim telah mencapai target yang telah ditentukan perusahaan dengan baik.

Fenomena yang dialami perusahaan harus segera ditanggulangi sebab akan menghambat tujuan perusahaan yang mungkin bisa mengarah pada kehancuran perusahaan tersebut. Oleh sebab itu, perusahaan harus mencari solusi yang tepat untuk meningkatkan kinerja karyawannya yaitu dengan cara memberikan motivasi dan 
meningkatkan kedisiplinan para karyawannya (Mulyadi, 2010).

Salah satu faktor yang mempengaruhi kinerja pegawai adalah motivasi. Motivasi kerja merupakan suatu hal yang sangat dibutuhkan oleh seorang pegawai, semakin tinggi motivasi kerja pegawai maka akan meningkatnya kinerja yang akan diberikan oleh pegawai tersebut kepada instansi tempat dimana mereka bekerja. Motivasi mempunyai kekuatan kecenderungan seseorang/individu untuk melibatkan diri dalam kegiatan yang mengarah kepada sasaran dalam pekerjaan sebagai kepuasan, tetapi lebih lanjut merupakan perasaan senang atau rela bekerja untuk mencapai tujuan pekerjaan.

Dengan hal ini, maka pimpinan PT. Federal Internasional Finance (FIF) Muara Enim sebagai pelaksana manajemen didorong untuk mencari jalan keluar guna mengatasi hal tersebut dalam rangka mempertahankan eksistensinya dan untuk mencapai tujuan perusahaan.

Berdasarkan fenomena penelitian di atas, maka penulis tertarik mengambil judul "Upaya Motivasi Untuk Meningkatkan Kinerja Karyawan Pada PT. Federal Internasional Finance (FIF) Di Muara Enim".

\section{I.2 RUMUSAN MASALAH}

Berdasarkan latar belakang yang telah diuraikan di atas, maka rumusan masalah dalam penelitian ini adalah

1. Faktor apa yang menghambat rendahnya disiplin karyawan pada PT. Federal Internasional Finance (FIF) Di Muara Enim?

2. Apa upaya untuk meningkatkan motivasi kerja dan kinerja karyawan PT. Federal Internasional Finance (FIF) Di Muara Enim?

\section{I.3 TUJUAN PENELITIAN}

Berdasarkan rumusan masalah tersebut, maka tujuan penelitian ini adalah untuk mengetahui motivasi karyawan dalam meningkatkan kinerja karyawan pada PT. Federal Internasional Finance (FIF) Di Muara Enim.

\section{I.4 MANFAAT PENELITIAN}

Hasil penelitian ini diharapkan dapat berharap dapat bermanfaat sebagai berikut :

a. Secara praktis :

penelitian ini sebagai bahan pertimbangan dan pengambilan keputusan yang berkaitan dengan motivasi kerja dan kinerja karyawan pada PT. Federal Internasional Finance (FIF) Di Muara Enim.

b. Secara teoritis :

Penelitian ini dapat memberikan kontribusi kepada ilmu pengetahuan khususnya mengenai motivasi kerja dan kinerja karyawan juga menambah kepustakaan di bidang sumber daya manusia.

\section{TINJAUAN PUSTAKA}

\section{II.1 Pengertian Motivasi Kerja}

Menurut Malthis (2006:114), motivasi adalah keinginan dalam diri seseorang yang menyebabkan orang tersebut bertindak. Biasanya orang bertindak karena suatu alasan untuk mencapai tujuan. Memahami motivasi sangatlah penting karena kinerja, reaksi terhadap kompensasi dan persoalan sumber daya manusia yang lain dipengaruhi dan 
mempengaruhi motivasi. Pendekatan untuk memahami motivasi berbeda-beda, karena teori yang berbeda mengembangkan pandangan dan model mereka sendiri.

Motivasi merupakan suatu permasalahan yang selalu ada dalam suatu organisasi, baik itu organisasi nirlaba atau bukan. Motivasi mempunyai peranan penting dalam pencapaian tujuan perusahaan, dapat dikatakan kemajuan suatu organisasi berawal dari motivasi yang dimiliki oleh para karyawannya. Banyak perusahaan yang selalu merefresh motivasi dalam bekerja agar selalu dapat membawa kemajuan, meskipun untuk itu perusahaan terkadang harus mengeluarkan biaya yang tidak sedikit demi pencapaian tujuan perusahaan lewat motivasi itu sendiri (Malayu Hasibuan SP, 2010:223).

Menurut Mangkunegara (2009:101), menyatakan beberapa teknik memotivasi kerja karyawan yaitu teknik pemenuhan kebutuhan karyawan dan teknik komunikasi persuasif.

Pencapaian tujuan suatu organisasi sangat bergantung kepada kemauan para pegawai untuk bekerja lebih giat. Agar pegawai bekerja lebih giat maka mereka perlu diberi motivasi dengan berbagai cara. Pada umumnya tingkah laku manusia dilakukan secara sadar, artinya selalu didorong oleh keinginan untuk mencapai tujuan tertentu. Disinilah letaknya peran penting dari motivasi.

\section{II.2 Tujuan Motivasi Kerja}

Motivasi merupakan kekuatan, dorongan, kebutuhan, semangat, tekanan, atau mekanisme psikologi yang mendorong seseorang atau sekelompok orang untuk mencapai prestasi tertentu sesuai dengan apa yang dikehendaki. Motivasi dirumuskan sebagai aktivitas individu untuk mencapai tujuan organisasi. Malayu Hasibuan SP (2007:97), menyatakan beberapa tujuan diadakannya motivasi kerja karyawan adalah

a. Mendorong gairah dan semangat kerja karyawan.

b. Meningkatkan moral dan kepuasan kerja karyawan.

c. Meningkatkan produktivitas kerja karyawan.

d. Mempertahankan loyalitas dan kestabilan karyawan perusahaan.

e. Meningkatkan kedisiplinan dan menurunkan tingkat absensi karyawan.

f. Mengefektifkan pengadaan karyawan.

g. Menciptakan suasana dan hubungan kerja yang baik.

h. Meningkatkan kreativitas dan partisipasi karyawan.

i. Meningkatkan tingkat kesejahteraan karyawan.

j. Mempertinggi rasa tanggungjawab karyawan terhadap tugas-tugasnya.

$\mathrm{k}$. Meningkatkan efisiensi penggunaan alat-alat dan bahan baku

\section{II.3 Pengertian Disiplin Kerja}

Menurut Malayu Hasibuan SP (2010:293) Disiplin kerja merupakan kesadaran dan kesediaan seseorang menaati semua peraturan perusahaan dan norma-norma yang berlaku.

Menurut Soegeng Prijodarminto (1993:24) Disiplin kerja didefinisikan sebagai suatu kondisi yang tercipta dan terbentuk melalui proses dari serangkaian perilaku yang menunjukkan ketaatan, kepatuhan, keteraturan dan, atau ketertiban.

Dari pengertian di atas, dapat disimpulkan bahwa disiplin kerja sangat penting sebab dengan kedisiplinan tersebut diharapkan karyawan mentaati peraturan, bekerja sesuai dengan prosedur sehingga pekerjaan terselesaikan secara efektif dan efisien serta dapat meningkatkan produktivitas karyawan.

\section{II.4 Pengertian Kinerja Karyawan}


Menurut Rivai, (2009:29) mengemukakan bahwa kinerja karyawan merupakan perilaku nyata yang ditampilkan setiap orang sebagai prestasi kerja yang dihasilkan oleh karyawan sesuai dengan perannya dalam perusahaan."

Menurut Robbins, P. Stephen \& Judge, (2010:38), kinerja adalah hasil akhir dari sebuah aktivitas. Pengertian tersebut bermakna bahwa, kinerja adalah hasil akhir dari suatu kegiatan. Sedangkan Menurut Sumarno, (2005) Kerjasama diantara sesama pekerja mendefinisikan kinerja karyawan adalah apa yang dilakukan atau tidak dilakukan karyawan dalam memberikan kontribusi kepada organisasi yang meliputi kuantitas output, kualitas output, jangka waktu output, kehadiran di tempat kerja, dan sikap kooperatif.

Berdasarkan definisi kinerja karyawan dari para ahli diatas, dapat disimpulkan bahwa kinerja merupakan kualitas dan kuantitas dari suatu hasil kerja (output) individu maupun kelompok dalam suatu aktivitas tertentu yang diakibatkan oleh kemampuan alami atau kemampuan yang diperoleh dari proses belajar serta keinginan untuk berprestasi.

\section{METODE PENELITIAN}

\section{III.1 Jenis dan Sumber Data}

Adapun jenis dan sumber data yang dikumpulkan penulis dalam penelitian ini adalah sebagai berikut :

1. Data Primer

Yaitu data dan informasi yang penulis peroleh langsung dari hasil wawancara langsung dengan para karyawan dari pimpinan perusahaan di PT. Federal Internasional Finance (FIF) Di Muara Enim.

2. Data Sekunder

Yaitu data yang diperoleh dari PT. Federal Internasional Finance (FIF) Di Muara Enim. Dengan membaca literatur yang ada hubungannya dengan objek penelitian ini.

\section{III.2 Teknik Pengumpulan Data}

1. Wawancara

Wawancara dengan karyawan PT. Federal Internasional Finance (FIF) Di Muara Enim. Hal ini untuk mendapatkan data dan keterangan langsung dengan melakukan tanya jawab.

2. Kuesioner

Penyebaran kuesioner yang berisi daftar pertanyaan yang berhubungan dengan variabel yang diteliti. Dalam penelitian ini, kuesioner yang diberikan kepada responden bersifat tertutup, dimana responden hanya memilih alternatif jawaban yang tersedia pada kuesioner.

\section{HASIL DAN PEMBAHASAN}

\section{IV.1 Faktor Penghambat Disiplin Kerja Karyawan}

Untuk mencapai tingkat keberhasilan yang tinggi, seorang manajer perusahaan harus melakukan upaya-upaya yang bisa meningkatkan semangat kerja karyawan, yaitu dengan memberikan motivasi agar karyawan disiplin kerja yang dapat mendorong seseorang karyawan dalam menyelesaikan tugas-tugas yang diberikan.

Adapun pelaksanaan disiplin kerja dilihat dari faktor yang berpengaruh di perusahaan yaitu:

1. Kepemimpinan 
Pelaksanaan disiplin kerja pegawai PT. Federal Internasional Finance (FIF) Muara Enim dilihat dari cara kepemimpinan yang dapat dijadikan panutan atau teladan bagi para bawahan sehingga bisa membangkitkan semangat dan gairah kerja serta bertindak sebagai motivator. Agar peraturan tata tertib karyawan di PT. Federal Internasional Finance (FIF) Muara Enim dilaksanakan dengan karyawan berusaha datang tepat waktu dan mengawasi serta membimbing bawahannya.

Kedisiplinan yang dimulai dari disiplin pemimpinnya agar dapat diikuti oleh bawahannya. Jika pimpinan memiliki rasa disiplin yang tinggi dalam etos kerjanya maka secara otomatis rasa disiplin diri itu juga dimiliki oleh para karyawannya. Hal ini dapat dilihat dari hasil angket yang penulis lakukan menunjukkan kedisiplinan yang berawal dari sikap kepemimpinan sangat baik.

2. Motivasi Kerja

Dengan adanya sikap kepemimpinan yang baik akan dapat memotivasi para bawahannya karena dengan keteladanan pemimpin dapat meningkatkan disiplin kerja karyawannya. Bukan sekedar takut akan sanksi yang akan dijatuhkan akan tetapi disiplin yang timbul dari kesadaran masing-masing karyawan. Dalam hal ini motivasi kerja sangat berpengaruh pada PT. Federal Internasional Finance (FIF) Muara Enim yang menunjukkan karyawan semakin termotivasi dengan adanya pelaksanaan disiplin kerja karyawan.

3. Komunikasi

Komunikasi merupakan kegiatan untuk saling memberi keterangan dan ide secara timbal balik yang diperlukan dalam setiap usaha kerjasama manusia untuk mencapai tujuan tertentu. Demikian juga pada PT. Federal Internasional Finance (FIF) Muara Enim yang menunjukkan bahwa komunikasi yang baik antara pimpinan dengan karyawannya.

4. Lingkungan Kerja

Lingkungan kerja yang baik akan menciptakan produktivitas kerja yang baik pula, demikian juga dengan pelaksanaan disiplin kerja karyawannya. Apabila sebagian besar karyawan melaksanakan disiplin kerja yang baik, maka tidak menutup kemungkinan karyawan yang lain akan terpengaruh utuk melaksanakan disiplin kerja yang baik pula. Pada PT. Federal Internasional Finance (FIF) Muara Enim menunjukkan bahwa tingkat kedisiplinan berpengaruh terhadap lingkungan kerja karyawan.

5. Balas jasa dan Sanksi

Untuk melaksanakan disiplin kerja karyawan, Pada PT. Federal Internasional Finance (FIF) Muara Enim menerapkan sistem keadilan, yaitu:

a. Dengan cara memberikan balas jasa yaitu melalui penghargaan (reward) bagi karyawan yang berkualitas dan bersikap disiplin selama bekerja,

b. Dengan memberikan hukuman (punishment) bagi karyawan yang tidak berdisiplin atau melanggar peraturan tata tertib selama bekerja.

Pemberian penghargaan (reward) dan hukuman (punishment) diberikan dengan maksud karyawan yang mendapatkan penghargaan (reward) tersebut semakin termotivasi dalam meningkatkan prestasi dan disiplin kerjanya. Tidak bisa dipungkiri bahwa penghargaan (reward) sangat diinginkan semua karyawan. Pemberian balas jasa melalui penghargaan sangat berpengaruh pada pelaksanaan disiplin kerja karyawan. Lain halnya dengan hukuman (punishment) tidak diinginkan karyawan akan tetapi pemberian hukuman (punishment) disini dimaksudkan sama dengan 
pemberian penghargaan (reward). Dengan adanya hukuman (punishment), semua karyawan tentu tidak menginginkannya dan secara otomatis bila karyawan tidak menginginkan hukuman, akan senantiasa mematuhi peraturan tata tertib dan meningkatkan kedisiplinan kerjanya. Dengan adanya sanksi dapat melaksanakan disiplin kerja yang baik. Hal ini dilaksanakan karena disiplin yang berlaku pada PT. Federal Internasional Finance (FIF) Muara Enim adalah disiplin preventif.

Hal ini sesuai dengan teori menurut Soegeng Prijodarminto (1993:24) Disiplin kerja didefinisikan sebagai suatu kondisi yang tercipta dan terbentuk melalui proses dari serangkaian perilaku yang menunjukkan ketaatan, kepatuhan, keteraturan dan, atau ketertiban

\section{IV.2 Upaya Untuk Meningkatkan Motivasi Kerja Dan Kinerja Karyawan PT. Federal Internasional Finance (FIF) Di Muara Enim}

Sebagian besar karyawan membutuhkan motivasi yang dapat menimbulkan perasaan senang dalam melakukan pekerjaannya tanpa merasa terbebani. Pemberian motivasi secara khusus kepada karyawan perlu dilakukan mengingat karakter, kemampuan dan keinginan tiap orang berbeda-beda.

Untuk itu pimpinan harus dapat memilih cara-cara tertentu dalam memberikan motivasi kepada karyawan agar motivasi tersebut dapat berhasil dan bermanfaat bagi perusahaan dan karyawan yang bersangkutan.

Upaya motivasi yang diberikan pimpinan PT. Federal Internasional Finance (FIF) Di Muara Enim kepada karyawannya dalam rangka meningkatkan kinerja karyawannya, yaitu sebagai berikut:

1. Adanya komunikasi antara atasan dengan bawahan untuk menghindari terjadinya kesenjangan sosial yang dirasakan oleh karyawan.

2. Pimpinan dapat secara langsung memberikan perhatian berupa pengarahanpengarahan dan petunjuk-petunjuk kepada karyawan atas pekerjaan masing-masing.

3. Memberikan kesempatan kepada karyawan untuk ikut berpartisipasi dengan menyumbangkan ide dan segala kreativitas dalam rangka mengembangkan skill dan keterampilan karyawan.

Adapun tujuan pemberian motivasi kepada karyawan, yaitu:

a. Untuk meningkatkan gairah kerja karyawan

b. Untuk meningkatkan prestasi kerja karyawan

c. Untuk meningkatkan disiplin kerja karyawan

d. Untuk meningkatkan rasa tanggung jawab karyawan atas tugas-tugasnya

e. Untuk meningkatkan produktivitas dan efektivitas kerja

Motivasi inilah yang dapat dijadikan pimpinan sebagai alat ukur untuk mengatur hubungan-hubungan pekerjaan diantara karyawan yang ada dalam perusahaan. Apabila pimpinan dapat memahami apa yang merangsang karyawan mau bekerja untuk perusahaan tersebut, maka pimpinan dapat menyesuaikan tugas-tugas pekerjaan dan imbalan-imbalan sehingga karyawan bergairah untuk bekerja.

Hal ini sesuai dengan teori menurut Malayu Hasibuan (2007:97), menyatakan beberapa tujuan diadakannya motivasi kerja karyawan

\section{IV.3 Pembahasan}

Penelitian ini bertujuan untuk mengetahui upaya untuk meningkatkan motivasi kerja dan kinerja karyawan PT. Federal Internasional Finance (FIF) Di Muara Enim 
yang diberikan dan sejauh mana tingkat motivasi yang digunakan, dengan harapan mendapatkan sumber daya yang berpotensi dan berkualitas baik. Produktivitas karyawan menjadi pusat perhatian dalam upaya meningkatkan kinerja yang mempengaruhi tingkat efisiensi dan efektivitas organisasi. Kinerja karyawan dapat dipengaruhi oleh faktor kemampuan dan motivasi, dimana jika kemampuan karyawan dan motivasi yang diberikan perusahaan sudah baik maka kinerja karyawan akan maksimal dan produktivitas karyawan semakin meningkat.

Untuk mencapai tingkat keberhasilan yang tinggi, pimpinan/manajer melakukan upaya untuk meningkatkan motivasi kerja dan kinerja karyawan dengan menerapkan disiplin kerja, mengadakan pengawasan terhadap kinerja karyawan baik pengawasan internal maupun eksternal, menciptakan situasi yang kondusif bagi karyawan, memberikan insentif, dan memberikan kompensasi yang adil bagi seluruh karyawan.

Segala program kesejahteraan karyawan yang ada, sebagian besar bertujuan menjadikan perusahaan sebagai rumah kedua, sehingga karyawan merasa kerasan, betah, dan mempunyai motivasi kerja yang tinggi dalam bekerja. Hal ini ada sebagian sesuai dengan teknik motivasi kerja karyawan yang dinyatakan Mangkunegara (2009:101) yaitu teknik pemenuhan kebutuhan dan teknik komunikasi persuasif, dimana teknik kebutuhan karyawan merupakan fundamental yang mendasari perilaku kerja, dan teknik komunikasi persuasif merupakan salah satu teknik memotivasi kerja karyawan yang dilakukan dengan cara mempengaruhi karyawan yaitu dengan memberikan perhatian langsung kepada karyawan.

Jenis motivasi PT. Federal Internasional Finance (FIF) Di Muara Enim adalah gaji, bonus, fasilitas kerja, penempatan jabatan, pujian, penghargaan, dan hukuman. Gaji merupakan bentuk imbalan yang harus diterima karyawan karena sudah melakukan pekerjaan, bonus adalah tambahan uang yang diberikan sebagai tanda ketekunan dalam bekerja, fasilitas kerja diberikan untuk menunjang efisiensi kerja karyawan, penempatan jabatan yang diberikan karyawan sesuai dengan keahlian masing-masing, pujian merupakan bentuk kepedulian perusahaan terhadap karyawan yang memiliki keunggulan lebih dalam bekerja, dan hukuman diberikan apabila seorang karyawan tidak bertanggung jawab terhadap pekerjaan yang diberikan.

Hal ini sesuai dengan jenis motivasi yang dinyatakan Malayu SP. Hasibuan (2007:150) yaitu motivasi positif dan motivasi negatif, dimana motivasi positif sebagai alat untuk meningkatkan semangat kerja karena pada umumnya manusia hanya senang menerima yang baik-baik saja, dan motivasi negatif merupakan bentuk motivasi berupa hukuman bagi karyawan yang pekerjaannya kurang baik. Motivasi kerja karyawan PT. Federal Internasional Finance (FIF) Di Muara Enim sudah berjalan baik. Hal ini terlihat pada ketepatan waktu kerja dan tanggung jawab karyawan dalam bekerja, yaitu karyawan mudah menyelesaikan pekerjaan tepat waktu.

Sebagai bentuk kepedulian perusahaan terhadap karyawan dan sikap tanggung jawab perusahaan terhadap karyawan, perusahaan menggunakan beberapa saluran komunikasi untuk menyerap keluhan, kritik, dan saran dari seluruh karyawan melalui komunikasi langsung dan tidak langsung. Komunikasi langsung dilakukan pimpinan dengan terjun langsung ke lapangan untuk mengetahui keluhan dan kritik dari para karyawannya, komunikasi tidak langsung dilakukan pimpinan bagi karyawan yang tidak berani atau malu mengungkapkan keluhan dan kritik secara langsung pada pimpinan. Perusahaan senantiasa menginformasikan perkembangan dan kondisi perusahaan secara continue kepada seluruh karyawan tanpa kecuali menjelaskan visi, misi, dan tujuan 
perusahaan. Hal ini dimaksudkan agar karyawan tidak hanya bekerja dan terjebak rutinitas, tetapi dapat mengetahui segala hal tentang tujuan perusahaan, sehingga dapat ditumbuhkan rasa memiliki antara karyawan dengan perusahaan, karena karyawan dipandang sebagai aset perusahaan.

Dalam hal ini manajemen perusahaan PT. Federal Internasional Finance (FIF) Di Muara Enim sesuai dengan pernyataan Mangkunegara (2009:100) yang menggunakan prinsip komunikasi, yaitu pimpinan mengkomunikasikan segala sesuatu yang berhubungan dengan usaha pencapaian tugas dengan informasi yang jelas dan tepat.

Tidak mudah seorang pemimpin mengelola seorang karyawannya. Untuk meningkatkan kinerja karyawan dibutuhkan waktu yang lama, karena kebutuhan dan keinginan setiap karyawan berbeda-beda. Salah satu yang digunakan pimpinan untuk meningkatkan kinerja yaitu dengan memberikan motivasi.

Pelaksanaan motivasi kerja tidak selamanya berjalan sesuai dengan rencana yang dibuat. Dalam memotivasi kerja karyawannya kendala yang dihadapi PT. Federal Internasional Finance (FIF) Di Muara Enim yaitu pimpinan sulit menentukan alat motivasi yang tepat dan efektif karena keinginan setiap karyawan tidak sama, pimpinan sulit mengetahui keinginan karyawan karena keinginan karyawan mudah berubah, karyawan kurang disiplin dalam pekerjaan yang menimbulkan pekerjaan belum terselesaikan dengan baik. Untuk menghadapi permasalahan tersebut, pimpinan melakukan pendekatan dan pengamatan langsung terhadap cara kerja karyawan untuk menentukan alat motivasi yang tepat untuk meningkatkan kinerja. Pimpinan dapat berkomunikasi langsung kepada karyawan tentang kebijakan yang dikeluarkan perusahaan dan juga disiplin kerja dapat ditingkatkan lagi.

\section{KESIMPULAN DAN SARAN}

\section{V.1 Kesimpulan}

1. Upaya pimpinan dalam meningkatkan kinerja melalui motivasi adalah meliputi penetapan disiplin, pengawasan, menciptakan iklim yang kondusif, pemberian insentif, dan kompensasi.

2. Jenis motivasi yang digunakan pimpinan untuk meningkatkan kinerja karyawan yaitu berupa gaji, bonus, fasilitas kerja, penempatan jabatan, pujian, penghargaan, dan hukuman

3. Dalam pelaksanaan kedisiplinan PT. Federal Internasional Finance (FIF) Di Muara Enim menerapkan sistem keadilan yaitu dengan cara pemberian penghargaan (reward) dan hukuman (punishment). Pelaksanaan kedisiplinan itu dilakukan secara langsung dengan segera melalui pendekatan preventif.

4. Upaya motivasi yang dapat di berikan pimpinan kepada para karyawannya dalam rangka meningkatkan kinerja karyawan, yaitu adanya komunikasi antara atasan dengan bawahan untuk menghindari terjadinya kesenjangan sosial yang dirasakan oleh karyawan.

\section{V.2 Saran}

1. Dalam pendelegasian wewenang dan menilai kinerja karyawan harus dilakukan sesuai dengan tanggung jawab secara continue, dengan memperhatikan keinginan karyawan terutama keinginan karyawan dalam target penjualan untuk memiliki keadilan kerja dan penilaian terhadap kinerja karyawan. 
2. Seluruh karyawan diharapkan mempunyai rasa tanggung jawab yang besar terhadap tugas yang diberikan, sehingga pekerjaan dapat terselesaikan dengan tepat waktu.

3. Pelaksanaan kedisiplinan pada PT. Federal Internasional Finance (FIF) Di Muara Enim diharapkan semakin ditingkatkan dan peraturan yang ditetapkan harus lebih dipertegas untuk ditaati karyawan.

4. Komunikasi antara pimpinan dengan para karyawan sebaliknya lebih ditingkatkan agar menjadi lebih baik serta lingkungan kerja dapat diciptakan lebih baik lagi.

\section{DAFTAR PUSTAKA}

Hasibuan, Malayu S.P. 2007. Organisasi dan Motivasi:Dasar Peningkatan Produktivitas. Jakarta: Bumi Aksara.

\section{Bumi Aksara}

2010. Manajemen Sumber Daya Manusia. Jakarta:PT.

Malthis. 2006. Manajemen Sumber Daya Manusia. Salemba Empat. Jakarta.

Mangkunegara, A. Anwar Prabu. 2009. Manajemen Sumber Daya Perusahaan. Bandung:Remaja Rosdakarya.

Mulyadi, H. 2010. Pengaruh Motivasi Dan Disiplin Kerja Terhadap Kinerja Karyawan Pada Departemen Weaving

Notoatmodjo, Soekidjo. 2003. Pengembangan Sumber Daya Manusia. Jakarta: Rineka Cipta

Prijodarminto, Soegeng. 1993. Disiplin: Kiat Menuju Sukses. Jakarta: Pradnya Paramita

Rivai, V. \& E. J. 2009. Manajemen Sumber Daya Manusia untuk Perusahaan. Jakarta: PT Raja Grafindo.

Robbins, P. Stephen \& Judge, T. A. 2010. Perilaku Organisasi. Jakarta: Salemba Empat

Sumarno, J. 2005. Pengaruh Komitmen Organisasi Terhadap Hubungan Antara Partisipasi Anggaran dan Kinerja Manajerial (Studi Empiris Pada Kantor Cabang Perbankan Indonesia Di Jakarta). Solo: Sna Viii Solo. 